\title{
Land Surface Evaluation Using Unit Hydrograph Methods at Way Besai Watershed, Sumberjaya, West Lampung, Indonesia
}

\author{
Tumiar Katarina Manik \\ Department of Agnonomy, Faculty of Agriculture, University of Lampung, Jl. Sumantri Brojonegoro No. 1 \\ Bandarlampung 35145, Indonesia, phone: +62-721-781820, e-mail: katarina.manik@gmail.com
}

Received 11 November 2009 / accepted 15 October 2010

\begin{abstract}
Sumber Jaya is an important water resource area for Lampung Province; therefore the local government protects this area, especially from clearing the forest for coffee plantation. However, the efforts in protecting the forest area had created conflict with the local farmers. The objective of this research was to evaluate catchments hydrological function from different land cover condition. The method using for this purpose was by investigating the unit hydrograph of each land cover which were observed from several rain events. The results showed that soil cover on each sub-catchment were relatively able to hold the input water. When rain falls, water was infiltrated into the soil before flow to the streams and water level increased slowly. When rain stops, water still flowed from the soil surface that water level did not decrease quickly. It can be concluded that the watershed surface was still in a good condition; however, watershed managements to prevent it from future destruction was necessary. The rest of forest area $(12 \%)$ should be protected and no further coffee plantation in this area was allowed.
\end{abstract}

Keywords: Unit hydrograph, water level, watershed

\section{INTRODUCTION}

Land use changes have been continuous since the beginning of civilization, especially for agricultural activities (Bellot et al. 2001). Changes in land use and resulting land cover throughout the world have caused important effects on natural resources through deterioration of soil and water quality, loss of biodiversity, and in the long-term, through changes in climate systems. This situation has stimulated research that aims to better understand the factors driving land use and cover change and the effects of these changes on the environment (de Koning et al. 1998).

At the local and regional scales, forests are crucial for maintaining the stability of rivers and watersheds. National and regional concerns for forest conversion and reforestation most often focus on the loss of the watershed functions of natural forests. The loss of watershed functions can be a combination of on-site concerns such as loss of land productivity because of erosion, off-site concerns related to water quantity and concern about water quality including siltation of reservoirs (Krairapanod and Atkinson 1998; Susswein et al. 2000).

J Trop Soils, Vol. 16, No. 1, 2011: 69-76

ISSN 0852-257X
Sumber Jaya is a district in West Lampung, Sumatra. The long mountain range in Sumatra, Bukit Barisan and Sumber Jaya is located at the end of this range. Sumber Jaya $(54,194$ hectares) is located at the upper part of Tulang Bawang watershed, known as Way Besai watershed. Tulang Bawang River drains an area of 998,300 ha (Verbist and Pasya 2004). Therefore, the local government considers Sumber Jaya as a major water resource for Lampung Province and an electric power generation plant was built in this area. Sumber Jaya has recently become a focal point of discussion in local and national governments. These discussions centre on the widespread conversion of forestland to coffee plantations and human settlements and the associated environmental and hydrological problems.

Coffee plantations continue to support local economies with short-term economic returns even in the current monetary crisis in 1977; in fact, the profitability of coffee plantations brought many people to Sumber Jaya (Budidarsono et al. 2000). Coffee is also one of the main products of Lampung Province; $15 \%$ of Indonesian coffee production in 2001 came from Lampung (Verbist et al. 2002). However, the long-term sustainability of such forest conversion practices is indeed questionable.

The rapid rate of forest conversion to coffee plantations after 1976 triggered a conflict between the provincial forest department and the settlers. 
The officers accused the local people of not employing conservation practices in managing these formerly forested areas, thus leading to rapid degradation and destruction of watershed functions. Without any communication with the local people, the government declared new forest borders to prevent the area from being further degraded; this action caused a serious conflict between government and the local people from 1990 to 1996. Even though forests are important for many reasons, preventing the people from securing a livelihood from forests in this region will not solve the problems; it even will complicate the social problems (Kusworo 2000).

To resolve this situation, ICRAF proposed agroforestry systems (coffee in multistrata systems) as an alternative. The concept assumes that agroforestry mosaics are as effective in protecting watershed function as the original forest cover, and hence a substantial share of current conflicts between state forest managers and local people can be resolved to mutual benefit (ICRAF 2001). As the ICRAF program continues, it is necessary to conduct research to assess watershed functions at larger scales. A research project that included many watershed aspects (e.g., rainfall distribution, water discharge, water quality, sedimentation and biodiversity) was initiated in 2002 by ICRAF in corporation with ACIAR; one part of this collaboration included the research for my thesis which focuses on the relationship between rainfall distribution and watershed water quantity using different hydrological methods.

Evaluation of watershed function mostly has been done through converting temporal and spatial rainfall distributions to runoff or constructing the hydrographs. Although the rainfall/runoff process is highly nonlinear, several linear methods such as the unit hydrograph are still recommended. Major assumption of the unit hydrograph approach is the linear relationship between runoff rates and rainfall excess amount.

Sherman (1932) introduced unit hydrograph more than 60 years ago by deriving it from observed runoff and rainfall data. After that the concept of unit hydrograph were developed with various approach, such as Clark (1945) using timedistributed technique, Nash (1957) with linear reservoir model, and Rodriguez-Iturbe and Valdes (1979) based on watershed geomorphologic conditions and many more recent concepts.

Guo (2006) used kinematic wave approach and collected data from several urbanized watersheds ranging from 1 to $5 \mathrm{sq} \mathrm{mi}$ and found that this approach is doing well for regular or ideal watershed geometry. Chiang, Tachikawa and Takara (2004) used a distributed instantaneous unit hydrograph and applied it to the Yasu River Basin in Japan (377 $\mathrm{km}^{2}$ ). The unit hydrograph used DEM to extract the watershed topographic feature. Since land use, land cover, and rain intensity are the most important factors that control rainfall-runoff mechanism, this DEM approach is suitable for real time flood forecasting purpose over ungauged watershed.

Unit hydrograph could be used to evaluate land use change since rainfall-runoff regime could change due to land cover changes due to human impacts. Jenicek (2007) used unit hydrograph method in evaluating the land use changes effect on runoff in Chomutovka Basin in Czech Republic. The results showed that decreasing influence of land use by increasing flood extremity was approved, and applied unit hydrograph with SCSCN (Soil Conservation Service Curve Number) method was suitable even though precise parameters were required.

The unit hydrograph for catchments could also be constructed from observations of input and responses from several significant storms of approximately equal duration. By plotting the unit hydrographs from all catchments together, the peak response and recession rates could be determined using the graph trend line on the Excel spreadsheet.

The objective of this research was to evaluate the Sumberjaya Watershed condition that is affected by rapidly changing land cover using unit hydrograph methods.

\section{MATERIALS AND METHODS}

\section{Research Site}

This research was located at Sumber Jaya

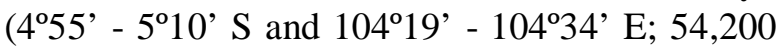
ha) inside Way Besai Watershed, West Lampung, Indonesia. Data was taken by the end of dry season and during wet season 2005.

The catchments for the study were arranged in nested structure (Figure 1) in order that relationship of rainfall-runoff in increasing scale with different land use could be investigated. The study subcatchments were located at the upper part of the watershed from Bodong Jaya to Suka Jaya, one of the catchment was in Bukit Rigis Forest Area. There were 8 sub-catchments with an area from 2.81 ha to 67.68 ha with different land covers (Table 1).

Six tipping bucket rain gages were installed atop $1.2 \mathrm{~m}$ poles on the hillslopes of each subcatchment. Each gage was equipped with data loggers which recorded the rainfall at $2 \mathrm{~min}$ 


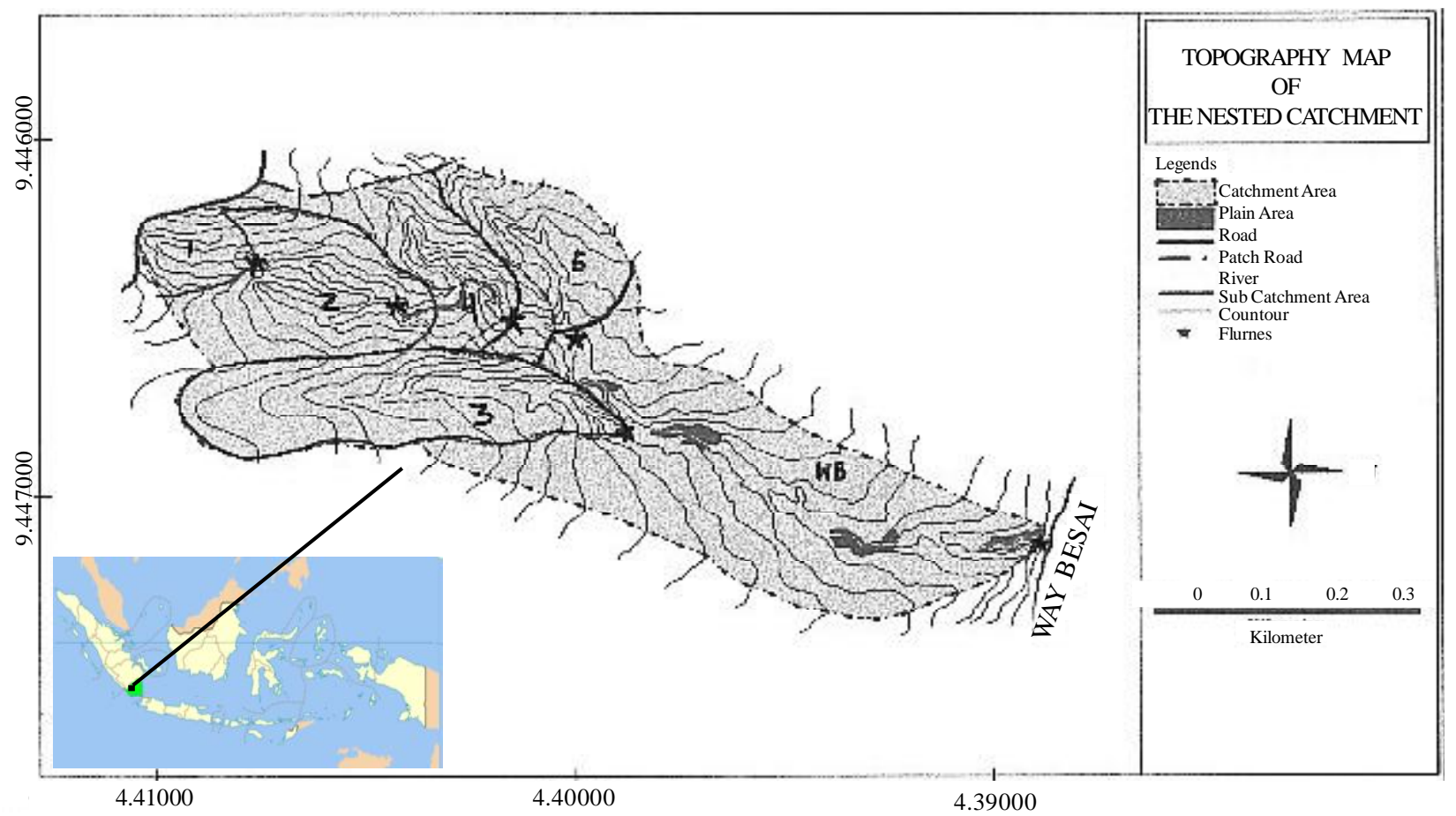

Figure 1. Sub-Catchments of the study area located inside Sumber Jaya Watershed.

Table 1. Sub-catchments of the research area, mean slope and vegetation type of the land cover.

\begin{tabular}{|c|c|c|c|}
\hline Catchment & Area (ha) & Mean Slope (\%) & Vegetation coverage \\
\hline Catchment 1 & 2.84 & 29 & $\begin{array}{l}\text { Mono coffee, Bushes (Imperata } \\
\text { cylindrica) }\end{array}$ \\
\hline Catchment 2 & 8.21 & 46 & Mono coffee, Imperata cylindrica \\
\hline Catchment 3 & 12.39 & 33 & $\begin{array}{l}\text { Mono coffee, Imperata Cylindrica, } \\
\text { coffee mixed with Glinicida } \\
\text { sepium }\end{array}$ \\
\hline Catchment 4 & 20.45 & 20 & $\begin{array}{l}\text { Mono coffee, Imperata Cylindrica, } \\
\text { coffee mixed with Gliricida sepium }\end{array}$ \\
\hline Catchment 5 & 27.22 & 26 & $\begin{array}{l}\text { Coffee mixed with various fruit trees } \\
\text { and shaded trees (Agro-forest), mono } \\
\text { coffee, Imperata cylindrica }\end{array}$ \\
\hline Catchment WB & 67.68 & 26 & $\begin{array}{l}\text { Paddies, sweet bark, coffee mixed with } \\
\text { Gliricida sepium, Imperata cylindrica }\end{array}$ \\
\hline Catchment AF & 4.39 & 29 & Coffee with various fruit trees \\
\hline Catchment FR & 10.33 & & Various wood trees \\
\hline
\end{tabular}

intervals and were periodically connected directly to a computer. Parshall flumes of standard dimensions were installed at the outlets of each subcatchment to monitor stream flow. The size of the flumes was determined based on catchment area, the size of the stream, and the likely height of the water during major storm events (Figure 2). Water level was measured by an automatic water level recorder Hobo level probe type LH-10 submersible pressure transmitter for level measurement.

\section{Data Analysis}

The unit hydrographs were constructed from observations of inputs and response for several significant storms of approximately equal duration with the steps as follows: (a) four or five hydrographs (for example, rain event in August $2^{\text {nd }}$ 2005 on Figure 3) were selected, (b) plot each hydrograph and separate event response from base flow, (c) for each hydrograph, were divided the ordinates by the corresponding value of effective rainfall to give the unit hydrograph ordinates for 

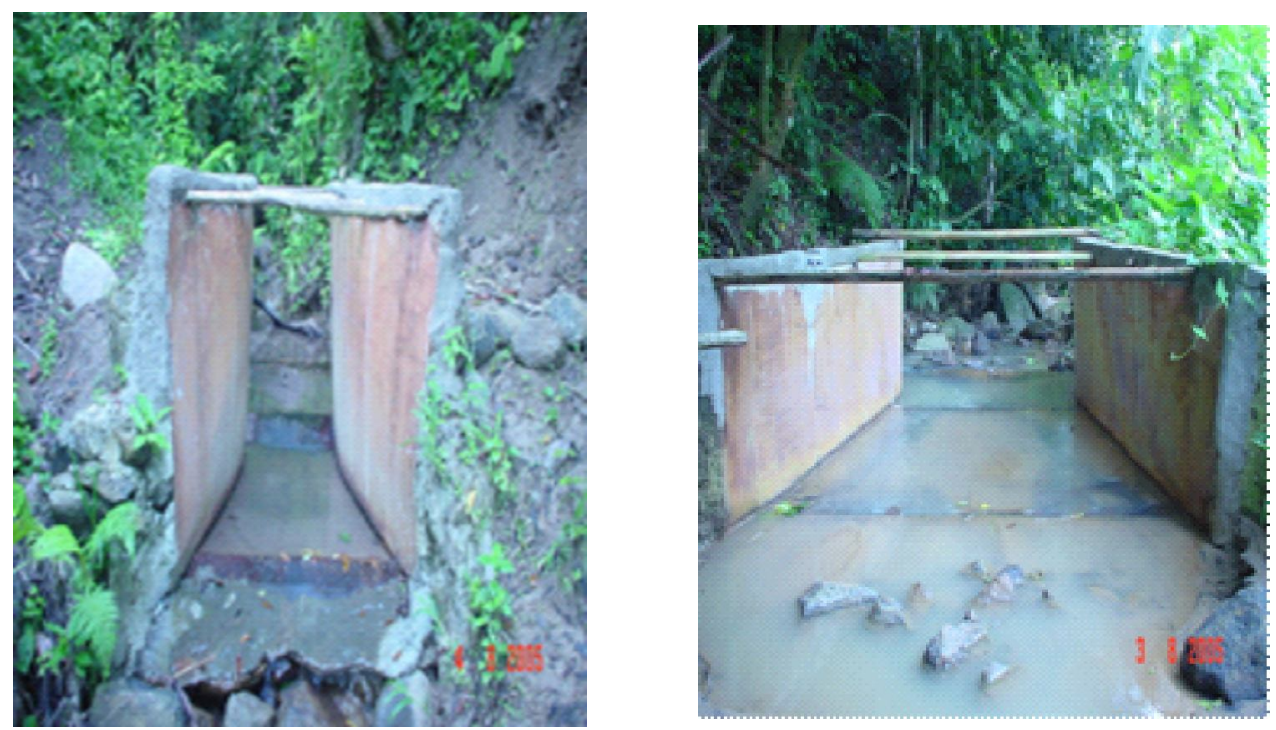

Figure 2. Parshall Flume with automatic water level for different catchments size.

Table 2. Quantitative description of the unit hydrograph.

\begin{tabular}{lllllll}
\hline & Peak rate & Recession rate & $\begin{array}{l}\text { Response } \\
\text { time } \\
(\mathrm{min})\end{array}$ & $\begin{array}{l}\text { Starting } \\
\text { discharge }\end{array}$ & $\begin{array}{l}\text { Discharge } \\
\text { peak } \\
\left(\mathrm{m}^{3} \mathrm{~s}^{-1}\right)\end{array}$ & $\begin{array}{l}\text { Average } \\
\text { total } \\
\text { discharge }\end{array}$ \\
\hline Catchment 1 & $\mathrm{Q}=0.0739 \ln (\mathrm{t})+0.6948$ & $\mathrm{Q}=-0.0054 \mathrm{t}+1.0516$ & 23.496 & 0.000106 & 0.0049 & 0.129 \\
Catchment 2 & $\mathrm{Q}=0.0834 \ln (\mathrm{t})+0.6903$ & $\mathrm{Q}=-0.0056 \mathrm{t}+1.0576$ & 34.349 & 0.000112 & 0.0196 & 0.423 \\
Catchment 3 & $\mathrm{Q}=0.1116 \ln (\mathrm{t})+0.626$ & $\mathrm{Q}=-0.0083 \mathrm{t}+1.0762$ & 36.726 & 0.000107 & 0.026 & 0.569 \\
Catchment 4 & $\mathrm{Q}=0.0798 \ln (\mathrm{t})+0.6998$ & $\mathrm{Q}=-0.0080 \mathrm{t}+1.0670$ & 36.945 & 0.000202 & 0.028 & 0.607 \\
Catchment 5 & $\mathrm{Q}=0.0939 \ln (\mathrm{t})+0.6581$ & $\mathrm{Q}=-0.0071 \mathrm{t}+1.0704$ & 43.833 & 0.000898 & 0.048 & 0.911 \\
Catchment WB & $\mathrm{Q}=0.0837 \ln (\mathrm{t})+0.5776$ & $\mathrm{Q}=-0.0021 \mathrm{t}+1.0874$ & 220.035 & 0.000129 & 0.045 & 4.31 \\
Catchment AF & $\mathrm{Q}=0.0729 \ln (\mathrm{t})+0.7345$ & $\mathrm{Q}=-0.0058 \mathrm{t}+1.0487$ & 29.108 & 0.000113 & 0.002 & 0.041 \\
Catchment FR & $\mathrm{Q}=0.0833 \ln (\mathrm{t})+0.7103$ & $\mathrm{Q}=-0.0253 \mathrm{t}+1.0919$ & 27.476 & 0.000348 & 0.0073 & 0.112 \\
\hline
\end{tabular}

the individual storm, (d) plot the unit hydrographs on the same graph, each beginning at the same time (Figure 5), (e) determine the peak of the composite unit graph as the average of all peaks, and plot the average peak at the average time of occurrence of all the peaks, and (f) the unit hydrographs from all catchments were plotted and the peak response during the rainfall and recession rates when the rain was stopped was determined using the graph trend line on the Excel spreadsheet (Table 2).

\section{RESULTS AND DISCUSSION}

Results show (Figure 3) that most catchments had similar peak discharge rates $\mathrm{Q}=0.0729-0.0837$ $\ln (\mathrm{t})$ with $\mathrm{Q}=$ peak discharge rate and $\mathrm{t}=$ time (minutes); exceptions were catchments 3 and 5, which had slightly higher rates $(\mathrm{Q}=0.0939$ and $0.1116 \ln (\mathrm{t}))$. In general, stormflow increased slowly in the study catchments; this indicated that most of the water was stored within the catchments

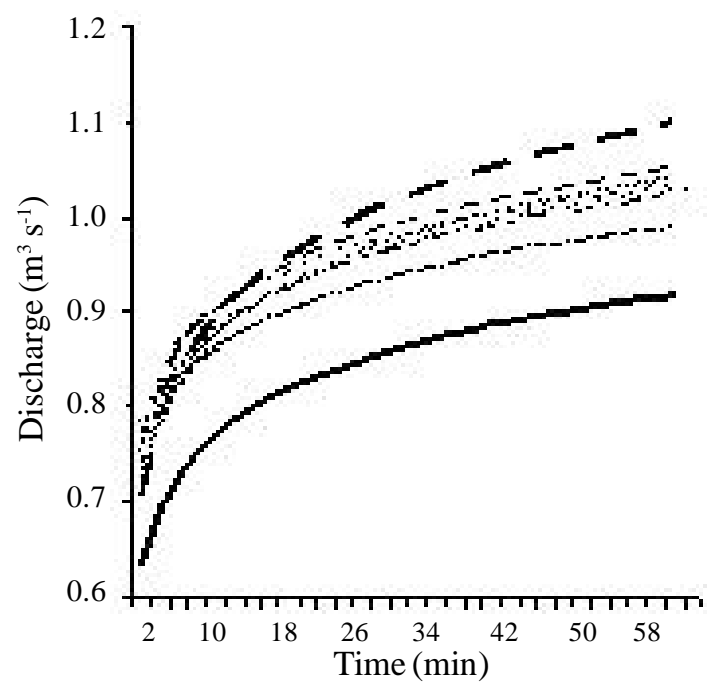

Figure 3. Peak response $\left(\mathrm{m}^{3} \mathrm{~s}^{-1}\right)$ on the Parshal flume for $1 \mathrm{~mm}$ rainfall. ...---- = catchment $1, \ldots \ldots$. $=$ catchment $2, \ldots-=$ catchment $3, \ldots . . .=$ catchment $4, \ldots . . . \ldots \ldots . . .=$ catchment $5,-=$ catchment $\mathrm{AF}, \ldots=$ catchment $\mathrm{WB}$, and -... = catchment FR. 

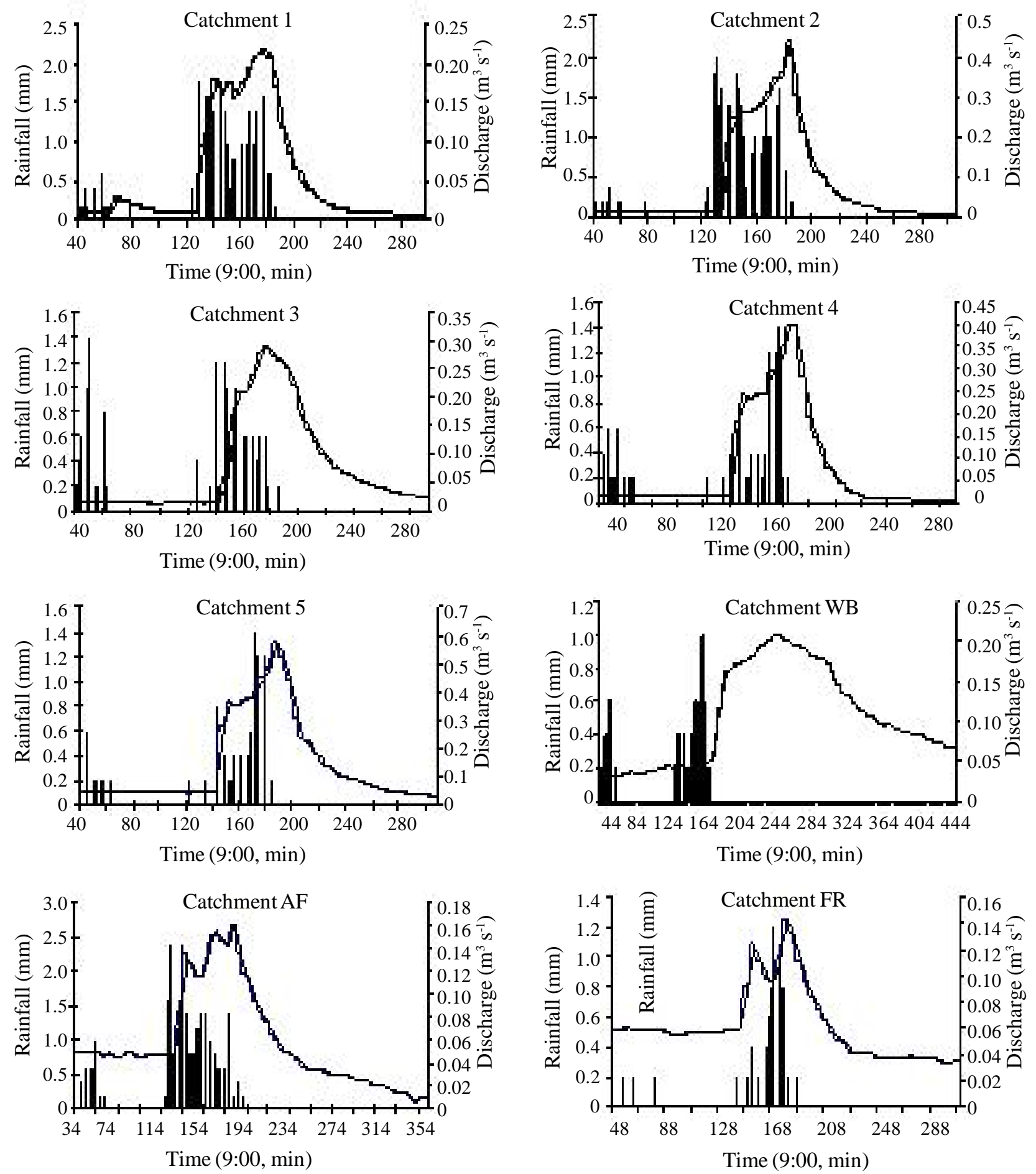

Figure 4. Hydrographs of each catchment for rain event on 2 August 2005.

rather than directly contributing to storm runoff in streams as quick flow.

It is interesting to observe that peak runoff responses from the agroforestry catchment were similar to those in catchment $1(\mathrm{Q}=0.0729 \ln (\mathrm{t})$ and $\mathrm{Q}=0.0739 \ln (\mathrm{t})$ respectively), while peak responses in the forest catchment $(\mathrm{FR})$ were similar to catchment $2(\mathrm{Q}=0.0833 \ln (\mathrm{t})$ and $\mathrm{Q}=0.0834 \ln (\mathrm{t})$, respectively); however, these results did not suggest that land cover had no effect on discharge. Discharge rate from the agroforestry catchment was much lower $\left(0.041 \mathrm{~m}^{3} \mathrm{~s}^{-1}\right)$ compared to other catchments $\left(0.1\right.$ to $\left.4.3 \mathrm{~m}^{3} \mathrm{~s}^{-1}\right)$. Peak discharge rate is determined by the rate and duration of the input and the catchment characteristics. Since rainfall as the water input was considered heterogeneous and catchment characteristics varied, peak runoff response was not totally reflected by catchment land cover (Dingman 1993). Even though land cover might be similar but agroforestry system had denser canopies which were able to prevent rainfall in reaching land surface that the water input to the 

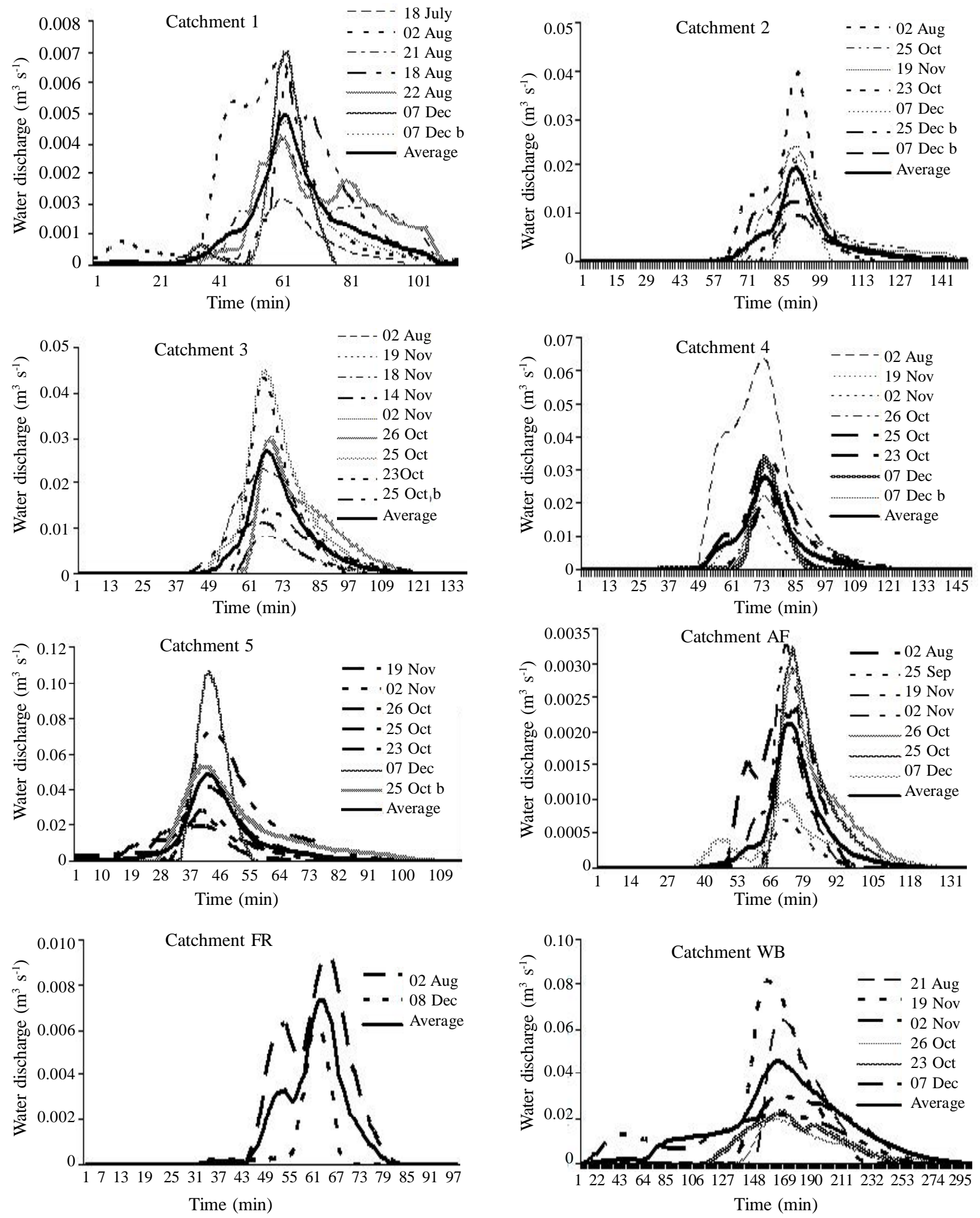

Figure 5. Unit hydrograph of every rain event and the average unit hydrograph.

catchment was lower, as the consequences, water discharge from the catchment was lower as well.

The same situation is true for the forest catchment. The peak responses of the forest catchment were similar with other catchments and so were the discharge rates $\left(0.114 \mathrm{~m}^{3} \mathrm{~s}^{-1}\right)$. Even though the discharge rate from the forest catchment was similar with catchment $1\left(0.129 \mathrm{~m}^{3} \mathrm{~s}^{-1}\right)$, significant storm flow response in the forest stream only occurred during 2 storms compared to 7 events in the other catchments. Thus, for most storms the forest catchment retained much of the water. Better than agroforestry catchment, forest catchment not only has dense canopy which keeps the rainfall from reaching land surface, but also has vegetation and humus on its surface that retain water longer, thus 


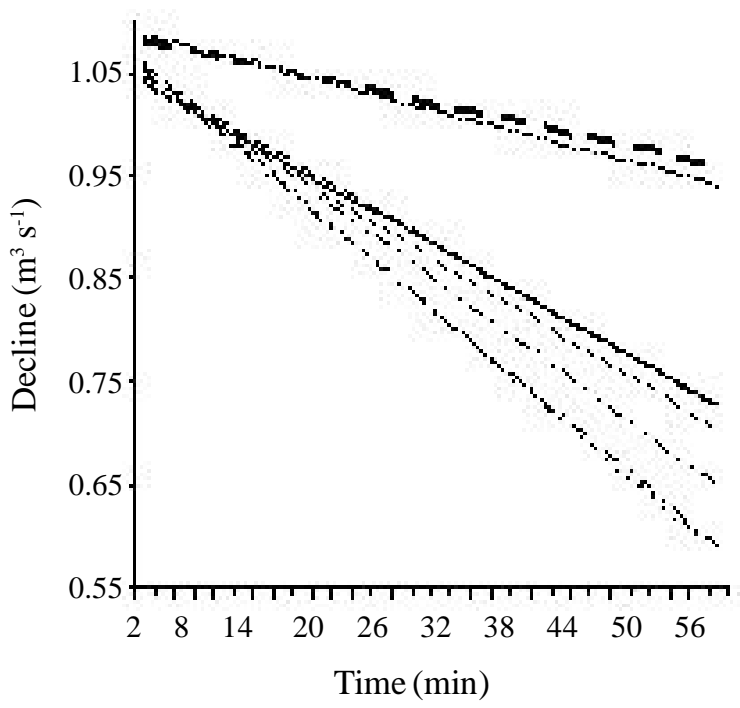

Figure 6. Recession limb on the Parshall flumes after the rain stopped. _- = catchment $1, \ldots=$ catchment $2, \ldots \ldots=$ catchment $3, \ldots . .=$ catchment $4, \ldots \ldots .=$ catchment $5, \ldots-=$ catchment $\mathrm{WB}, \ldots \ldots \ldots \ldots . . .=$ catchment AF, and ..-... = catchment FR.

only after several rain events that water level on the stream was arise.

Land use obviously affects peak runoff rate. A research by Indonesian Agro-Climate and Hydrology Research Institute (IAHRI 2003) on Cilalawi, Cikao and Ciherang Watersheds in West Java showed that peak runoff rate in 2002 when the land cover dominated by settlement, rubber and teak plantation increased compared to the peak runoff rate in 1992. The rate was $67.95 \mathrm{~m}^{3} \mathrm{~s}^{-1}$ compared to $64.38 \mathrm{~m}^{3} \mathrm{~s}^{-1}$ for Cilalawi; $10,02 \mathrm{~m}^{3} \mathrm{~s}^{-1}$ compared to $8,07 \mathrm{~m}^{3} \mathrm{~s}^{-1}$ for Cikao and $5,24 \mathrm{~m}^{3} \mathrm{~s}^{-1}$ compared to $4,75 \mathrm{~m}^{3} \mathrm{~s}^{-1}$.

The rate of water recession followed the water peak rate (Figure 6). Catchment WB had the slowest recession rate $\mathrm{Q}=0.0021 \mathrm{t}$ with $\mathrm{Q}=$ recession rate and $\mathrm{t}=$ time (minutes), followed by catchments 1 , 2 , and $\mathrm{AF}(\mathrm{Q}=-0.0054 \mathrm{t}, \mathrm{Q}=-0.0056 \mathrm{t}$ and $\mathrm{Q}=-$ 0.0058 t, respectively), with catchments 3,4 , and 5 having the fastest recession rates $(\mathrm{Q}=-0.0083 \mathrm{t}, \mathrm{Q}=$ $-0.008 \mathrm{t}$ and $\mathrm{Q}=-0.0071 \mathrm{t}$, respectively). Surprisingly, the forest catchment (FR) had the fastest recession rate $(\mathrm{Q}=-0.0253 \mathrm{t})$, but this was only documented for two discharge events compared with seven events in the other catchments.

The larger size of catchment WB along with the flat outlet area was the reason why the recession limbs of storm hydrographs were slowest in WB. Storm runoff continued to be routed from the upper catchments long after rainfall stopped. Although the similar recession rates in catchments 1,2 and $\mathrm{AF}$ may indicate that storage constants were similar, these did not reflect the same catchment characteristics. Comparing peak responses and recession rates, storm hydrographs generally exhibited slower rising limbs and more rapid falling limbs. This response pattern indicated that soils in the catchments were able to hold and store the water. When the rain started, rainwater initially infiltrated into the soil before flowing to streams; when the rain stopped, the discharge ceased rapidly.

Quantitative descriptions of storm discharge response on $1 \mathrm{~mm} \mathrm{hr}^{-1}$ effective rainfall could be calculated using this unit hydrograph method. Assuming that catchments respond linearly to rainfall inputs, both the hydrograph shape and discharge for different amounts of rainfall could be estimated from values in Table 2. For example, a 1 $\mathrm{mm} \mathrm{hr}{ }^{-1}$ rainfall on catchment 1 would generate an initial discharge of $0.000106 \mathrm{~m}^{3} \mathrm{~s}^{-1}$; this would increase based on the peak response equation with the recession dictated by the equation for the recession rate. A $2 \mathrm{~mm} \mathrm{hr}^{-1}$ rain would double the initial storm discharge, thereafter the peak response and recession rate would be the same.

Response time is the difference between beginning of hydrograph rise and the beginning of water input (Dingman 1993). In general, the most rapid response occurred in the smallest catchments: $23 \mathrm{~min}$ in catchment 1 (2.84 ha) compared to 44 min in catchment 5 (27.22 ha), and $220 \mathrm{~min}$ in WB (67.68 ha). However, the response did not always increase linearly with catchment size. Catchments 2,3 , and 4 had similar response times (34, 37 and 37 min with areas of $8.4,12.4$ and 20.5 ha, respectively).

The most rapid response was observed in catchment 1 ; this was related to the small catchment size (2.84 ha) and land cover, which was dominated by monoculture coffee plantations. The similar time constants obtained for the agroforestry (4.4 ha) and forest (10.3 ha) catchments did not imply that the better land cover of the forest catchment did not affect the travel time for water to reach the streams. Discharge rate from the agroforesty catchment was much lower $\left(0.041 \mathrm{~m}^{3} \mathrm{~s}^{-1}\right)$ compared to other catchments ( 0.1 to $\left.4.3 \mathrm{~m}^{3} \mathrm{~s}^{-1}\right)$. Therefore, the rapid discharge from the agroforestry catchment obviously came from saturated overland flow in the riparian area while other water was stored in the catchment. In general the results of this study was similar with a study by Cho and Olivera (2009) in three watershed in San Jacinto River watershed, USA found that spatial distribution of land use, soil type and precipitation influenced more on runoff depths than on the time the water reach the outlet. 
Catchments 2, 3, and 4, which had almost the same response time $(34,37$ and 37 min with areas of $8.41,12.39$ and 20.45 ha, respectively) actually had rather different slopes but similar land cover. In general, catchment 2 was steep (46\%) with monoculture coffee, catchment 3 was moderately steep $(33 \%)$ with monoculture coffee and shaded coffee, and catchment 4 was moderately sloping (20\%) with monoculture coffee and shaded coffee, it appeared that vegetation coverage somewhat nullifies the effect of slope.

\section{CONCLUSIONS}

Based on the average of hydrograph shape from the seven storms, all catchments had similar discharge peak rate $\left(\mathrm{m}^{3} \mathrm{~s}^{-1}\right)$; between $X=0.0729$ $0.1116 \ln (\mathrm{t})$. Water stage increased slowly in the streams of the study catchments during storms. This finding showed that most of the water was stored within catchments rather than directly routed to streams during storms.

These results showed that land surface condition in Sumber Jaya watershed which was reflected from the observed catchments was moderately good. Watershed management to prevent further land degradation is not too late. Even though watershed management needs to consider local people livelihood, it does not mean that forest conversion for new coffee plantation is allowed. Remained forest area $(12 \%)$ has to be protected and managed in serious effort and it can be operated with the participation of the local people. Through some extension programs they will understand the important of keeping the nature in sustainable scheme.

\section{ACKNOWLEDGEMENTS}

This research was made possible with financial support from ICRAF (International Centre for Research in Agroforest) and National University of Singapore. The writer appreciates the valuable suggestions and support from Prof. Roy C. Sidle (National University of Singapore).

\section{REFERENCES}

Bellot J, A Bonet, JR Sanchez and E Chirino. 2001. Likely effects of land use change on the runoff and aquifer recharge in a semiarid landscape using a hydrological model. Landscape Urban Plan 55: 41-53.

Budidarsono S, SA Kuncoro and TP Tomich. 2000. A profitability assessment of Robusta coffee system in Sumber Jaya watershed, Lampung, Sumatra, Indonesia. ICRAF Southeast Asia, Bogor, Indonesia.
Chiang S, Y Tachikawa and K Takara. 2004. RainfallRunoff Simulation By Using Distributed Instataneous Unit Hydrograph Derived From A Applying Flow Accumulation Value Of DEM. Апnи J Hydraulic Eng JCCE 48: 1-6.

Cho, H and Fransisco Olivera. 2009. Effect of The Spatial Variability Of Land Use, Soil Type and Precipitation on Streamflow in Small Watershed. J Am Water Res Assoc 45 (3): 673-686.

Clark CO. 1945. Storage and The Unit Hydrograph. Tran ASCE 110: 1419-1446.

De Koning GHJ, A Veldkamp, LO Fresco. 1998. Land use in Ecuador: A statistical analysis at different aggregation levels. Agric Ecosyst Environ 70: 231-247.

Dingman, Lawrence, S. 1993. Physical Hydrology. Prentice Hall. New Jersey, USA.

Guo, James, C.Y. 2006. Storm Water Predictions by Dimensionless Unit Hydrograph. Journal of Irrigation and Drainage Engineering 132 (4): 410

IAHRI [Indonesian Agroclimate and Hydrology Research Institute]. 2003. Pengaruh Perubahan Lahan Terhadap Aliran Permukaan, Sedimen dan Produksi Air Daerah Aliran Sungai. Laporan Penelitian (in Indonesian).

ICRAF [International Centre for Research in Agroforestry]. 2001. What is Agroforestry ?. International Research for Agroforestry, Bogor, Indonesia.

Jenicek M. 2007. Effect of Land Cover on Runoff Process Using SCS CN Method in The Upper Chomutovka Catchment. In: Proceeding of the $1^{\text {st }}$ Scientific Conference on Integrated Catchment Management for Hazard Mitigation 24-26 September 2007. Remote Sensing Department, University of Trier, pp. 42-46.

Krairapanod N and A Atkinson. 1998. Watershed management in Thailand: Concepts, problems and implementations. Regul River 14: 485- 498.

Kusworo A. 2000. Perambah Hutan atau kambing hitam. Pustaka Latin, Bogor, Indonesia (in Indonesian).

Nash JE. 1957. The form of the instantaneous unit hydrograph. IAHS Publ 45 (3): 114 -121.

Rodriguez-Iturbe I and JB Valdes. 1979. The geomorphic structure of hydrologic response. Water Resour Res 15(6): 1409- 1420.

Sherman LK. 1932. Stream flow from rainfall by the unit-graph method. Eng News Rec 108: 501- 503.

Susswein PM, M. Van Noordwijk and B Verbist. 2000. Forest watershed functions and tropical land use change. ASB Lecture note 7. International Centre for Research in Agroforestry, Bogor, Indonesia.

Verbist B and G Pasya. 2004. Perspektif sejarah status kawasan htan, konflik dan negosiasi di Sumber Jaya, Lampung Barat- Propinsi Lampung. Agrivita 26 (1): 20-28.

Verbist B, AED Putra and S Budidarsono, 2002. Sumber Jaya Land Use Change, History and Its Driving Factors. Backgrounds for ACIAR Project Planning Meeting. Sumber Jaya, Lampung, Indonesia, 12 16 October 2002. 